Albayrak, H. (2020). Sosyal hizmetin anlatı araştırması ile buluşması. Toplum ve Sosyal Hizmet, 31(4), 1719-1745.

Derleme

Makale Geliş Tarihi:30.05.2020

Makale Kabul Tarihi: 03.09.2020

\title{
SOSYAL HİMETIN ANLATI ARAŞTIRMASI İLE BULUŞMASI
}

\author{
Locating Narrative Inquiry with Social Work
}

\author{
Hande ALBAYRAK*
}

* Dr., Kocaeli Üniversitesi Sağllk Bilimleri Fakültesi Sosyal Hizmet Bölümü, ORCID ID: 0000-

0002-2972-9490, e-posta: hande.albayrak@kocaeli.edu.tr

\section{ÖZET}

Bu çalışmanın temel amacı anlatı anlayışını ve araştırmasını tanımlayarak sosyal hizmet araştırması ve uygulaması için bir yaklaşım sunmaktır. Anlatı araştırmalarına dair yapılan literatür taramasında sosyal hizmette anlatıya dönüşün görünürlülüğü de ele alınmıştır. Felsefi köklerini postmodernizm, sosyal inşacılık, yapılandırmacılık ve feminizden alan anlatı anlayışı ve araştırmaları yaygınlaşarak, bugün hemen hemen her disiplindeki çalışmalara yansımaya başlamıştır. Bu yüzden de anlatı araştırmasının, sosyal hizmet disiplini çerçevesinde tanıtılması önem taşımaktadır. Çalışmada öncelikle deneyim, anlatı, hikaye gibi temel kavramlar bağlantısal olarak açıklanmıştır. Kavramlara dair oluşturulan anlayışın ardından anlatı araştırması, görüşme süreci, hikayenin oluşumu ve analiz biçimleri tanımlanmıştır. Son olarak ise sosyal hizmet araştırmalarında ve uygulamalarında sessizleştirilen ve ötekileştirilen bireylerle çalışma konusu meta ve karşıt anlatılar bağlamında ele alınmıştır.

Anahtar kelimeler: Anlatı araştırması, anlatı, hikaye anlatımı, sosyal hizmet

\begin{abstract}
The main purpose of this study is to define an understanding of narrative and narrative inquiry and to provide an approach for social work research and practice. In the literature review on narrative studies, the visibility of the narrative turn in social work was also examined. The understanding of narrative and narrative research, which takes its philosophical roots from postmodernism, social constructivism, contructivism and feminism has become widespread and is reflected in studies in almost every discipline today. Therefore, it is important to introduce narrative research within the framework with social work discipline. In the study, firstly, basic concepts such as experience, narrative and story are explained in relational. Following the understanding of the concepts, narrative research, interviewing process, formation of the story and analysis forms is defined. Finally, the issue of working with individuals who are silenced and marginalized in social work researches and practices has been addressed in the context of meta and counter narratives.
\end{abstract}

Key words: Narrative research, narrative, storytelling, social work 


\section{Giriş}

Son yıllarda özellikle sosyal hizmet, psikoloji, hemşirelik gibi birçok disiplinde de insana dair yaşantıların pozitivist bir anlayışla standartlaştırılmış testlerle anlaşılamayacağı düşüncesinin gelişmesiyle yaygın olarak nitel araştırma kullanılmaya başlandığı görülmektedir. Nitel araştırma yönteminin, yaklaşımlarının ve stratejilerinin temel ilkeleri doğrultusunda gerçekleşen anlatı araştırması ise bu kapsamda önemli bir alan haline gelmiştir. Anlatı araştırması, nitel araştırmanın fenomenoloji, kuram oluşturma, etnografi ve durum çalışması gibi nitel araştırma yaklaşımlarından biridir. Araştırmalarda anlatıya dönüş, elbette nitel araştırmalara yönelen ilgiyle birlikte ele alınmalıdır (Kim, 2016). 1960'ı yıllardan itibaren sosyal bilim alanlarından tarih, antropoloji, halk bilimi, psikoloji, sosyolinguistik, iletişim çalışmaları ve sosyoloji gibi disiplinlerde anlatı çalışmaları yapılmaya başlanmıştır (Riessman ve Quinney, 2005). Akademinin anlatıya olan bu ilgisinde ise 1960'ların ve 1970 'lerin hak hareketlerinin, normatif olan baskın hikayeleri reddetmeleri ve ötekileştirilmiş olanların sesini duyma çabası etkili olmuştur (Davis, 2014; Holstein ve Gubrium, 2011; Fraser ve MacDougall, 2017). Felsefi köklerini postmodernizm, sosyal inşacılık, yapılandırmacılık ve feminizden alan anlatı anlayışı yaygınlaşarak (Etherington, 2011), bugün hemen hemen her disipline ve mesleğe nüfuz etmiştir. 1980 ve 1981 yılında antropoloji, psikoloji, sanat tarihi, felsefe, edebiyat gibi alanlardaki anlatı çalışmaları iki sayı olarak Eleştirel Araştırma Dergisi'nde yayınlanmış ve derginin editörü, "anlatı araştırmasının artık sadece psikoloji ve dilbilimlerinin ilgi alanı olmadığını, insan ve doğal bilimlerinin tüm dallarında olumlu bir içgörü kaynağı haline geldiğini” belirtmiştir (Kim, 2016: 6). 1993 yılında Hayatların Anlatı Çalışması (Narrative Study of Lives) isimli yıllık seri ve Anlatı Araştırmaları (Narrative Inquiry) isimli dergi ile ise anlatı araştırmalarında disiplinlerarası çalışmaların ivme kazandığı belirtilmektedir (Chase, 2005 akt: Creswell, 2013). Anlatı araştırmalarına bu ilginin nedenini Bell ve Hydén (2017), pozitivist paradigmanın insanı anlamaya dair sunduğu sınırlı bilgi, post-yapısalcılığa artan ilgi, özgürleştirici hikaye anlatımının çekiciliği ve eyleyen öznenin gücü gibi çeşitli kaynaklara dayandırarak açıklamaktadır.

Anlatı araştırmasına yönelime dair bu genel bilgilerden sonra sosyal hizmet alanında anlatı araştırması kendine ne zaman ve hangi konularda yer bulmuştur? Sosyal hizmet disiplininde ilk olarak anlatı araştırmasını kullanan Laird (1988) olmuş, ardından Reissman (1990a) boşanma ve toplumsal cinsiyet konusunda yaptığı bir araştırmada kullanmıştır (Riessman, 2008). Daha sonraları ise çeşitli kitaplarda 
sosyal hizmet uzmanlarının anlatı araştırması üzerine yazıları ve araştırmaları olmuştur (Hall, 1997; Laird, 1993; Riessman, 1994; Shaw ve Gould, 2001). Ancak sosyal hizmet alanındaki dergilerine bakıldığında anlatı araştırmasının o zamanlar kendine yeterince yer bulamadığı görülmektedir. Sosyal hizmette anlatıya dönüşe bakıldığında; Riessman ve Quinney (2005), 1990-2005 yılları arasında sosyal hizmet alanında yayınlanan 200'den fazla makaleyi değerlendirerek yaptıkları çalışmalarında diğer alanların aksine sosyal hizmette anlatı araştırmalarının "yeterince iyi" yapıldığı çok az çalışma olduğu sonucuna ulaşmışlardır. Çalışmalarındaki bir diğer önemli bir sonuç ise, anlatı teorisinin sosyal hizmet uygulamasına bilgi olarak yansımasının, anlatı yöntemlerinin sosyal hizmet araştırmalarında yer bulmasından daha fazla gelişmiş olduğudur (Riessman ve Quinney, 2005). Benzer şekilde Riessman (2008)'a göre de sosyal hizmet araştırmasında, anlatı kavramları sınırlı düzeyde benimsenmiştir. Anlatı araştırmasının sosyal hizmet araştırmalarında yeterince yer bulamayışının nedenini; akademide (fon kaynakları, dergiler ve lisans üstü eğitim de dahil olacak şekilde) nesnel ve nicel araştırma metotlarına yönelimin olması; profesyonel alanın dışında kalanı okuyarak, kendi disiplininin çerçevesinden konuya bakmayı gerektiren anlatının doğası gereği çapraz disipliner olması; analizin genellikle çok ayrıntılı ve karmaşık verilere dayandığı için zaman alması gibi zorluklarla açıklamışlardır (Riessman ve Quinney, 2005). Son olarak ise sosyal hizmette anlatıya dönüşe dair önemli bir gelişme ise "Nitel Sosyal Hizmet (Qualitative Social Work)" Dergisi'nin 2017 yılında "Sosyal Hizmet ve Anlatıya (Kısmen?) Dönüş (Social Work and Narrative (Half?) Turn)" adında özel bir sayı çıkartarak, sosyal hizmette anlatı çalışmalarına ilginin artması konusunda teşvik edici bir yaklaşım benimsemeleridir.

Anlatı araştırmasındaki temel nokta, aynı sosyal hizmetteki gibi ilişkilerdeki insan etkileşimleridir. Anlatının fenomenolojide dayandığı bazı kökenler olsa da, uygulamalarda, artık yaşanmış deneyimin ve bireylerin "ardındaki" dünyaların ötesine doğru yönelim mevcuttur (Riessman ve Quinney, 2005). Bu noktada bireyleri ve yaşadıklarını derinlemesine anlamak ve uygun uygulamayı gerçekleştirebilmek için yaşanmış deneyimin ve bireylerin "ardındaki” dünyaların ötesine bakabilmek konusunda, anlatı anlayışının bilgisi yardımcıdır. Bilindiği üzere sosyal hizmet çalışmaları, çeşitli sorunlar yaşayan bireylerle görüşmeler yapılarak insanların yaşadıkları deneyimleri anlama ve sosyal değişimi ve gelişimi, sosyal bütünleşmeyi, insanların güçlendirilmesini ve özgürleşmelerini destekleme temelinde 
yapılmaktadır. Dolayısıyla anlatı anlayışı sosyal hizmetin bu amacı için derinlemesine bir anlayış sunması bakımından önemlidir.

$\mathrm{Bu}$ çalışmada anlatı anlayışını ve araştırmasını tanımlayarak sosyal hizmet araştırması ve uygulaması için bir yaklaşım edinmek amaçlanmıştır. Bu amaç doğrultusunda öncelikle deneyim, anlatı ve hikaye gibi kavramlar üzerinde durulduktan sonra anlatı araştırması genel hatları ile tanımlanmıştır. Ardından ise anlatı araştırması kapsamında görüşme sürecinin ve hayat hikayesini oluşturmanın nasıl olduğu ve buralarda araştırmacının rolü açıklanmıştır. Görüşmelere dair bilgilerden sonra anlatı araştırmasının analiz çalışmalarının çeşitlerine yer verilmiştir. Son olarak ise sosyal hizmet araştırmalarında ve uygulamaları kapsamında özellikle sessizleştirilen ve ötekileştirilen bireylerle çalışma konusu, meta ve karşıt anlatılar bağlamında ele alınmıştır.

\section{Temel Kavramlar: Deneyimden Anlatıya, Anlatıdan Hikayeye Giden Bir Süreç}

Anlatı araştırmasını anlamak için öncelikle "anlatı" kavramına, anlatının deneyimden farkına ve anlatının insanın hayat hikayesindeki yerine bakmak gereklidir. Çünkü anlatı araştırması Connelly ve Clandinin (1990)'in de belirttiği gibi, insanların bireysel ve sosyal olarak hikayeler anlattıkları ve hikayeleşen bir hayat sürdüklerinden yola çıkarak insanların dünyayı nasıl deneyimledikleri üzerine odaklanmaktadır. Bu odağın daha iyi anlaşılması için bahsedilen bu kavramların birbiri ile bağlantısı net bir şekilde açıklanmalıdır.

İlk olarak anlatı literatüründe geniş bir yer kaplayan deneyim kavramına bakıldığında, anlatının deneyimi kapsadığı görülmelidir. Deneyim, anlatı yoluyla oluşturulan ve insanların olayları ve karşı karşıya kaldıklarını anlamlandırmasını sağlayan bir şey olarak görülür (Riessman, 1993). Scott (1991) öz bir şekilde bunu, deneyimlerin anlamlandırılmasında anlatı/anlatımın işlevi olarak açıklamıştır. Bu, anlatıcının "benlik kavramı"nın bir parçası olarak ortaya çıkan bir meta-anlatı dahilinde deneyimleme ve yorumlama süreçlerinde bireylerin aktif rol aldıkları anlamına gelir. Dolayısıyla birey, meta anlatı doğrultusundaki deneyimleri yoluyla inşa edilmektedir. Örneğin bu duruma kadın deneyimi üzerinden bakılırsa, kadın deneyimi cinsiyet kimliğini kuran pratikler bütünü olarak ele alınmalıdır. Yani kadın deneyimi toplumsal cinsiyetin bir sonucu değildir (Scott, 1991: 779). Bu açıklamalar bireyin tarihsel, sosyal ve kültürel koşulları bağlamında deneyimlere dair anlatıların anlam kazandığını göstermektedir. Bu bağlamda anlatı, Uzun (2015)'un da ifade ettiği üzere deneyimin anlamlı hale dönüştürülmesinin bir yolu olarak görülmektedir. 
Deneyimlerden kaynaklanan algılamalar yoluyla, insanlar fikir geliştirir ve bunları belirli sosyal, kültürel ve tarihsel bağlamda anlatıya dönüştürür.

Anlatı ise, insanın yaşadığı çeşitli olayları ve eylemlerini amaç odaklı süreçlerle tematik olarak birleştirerek bir araya getiren söylem kompozisyonunun türüdür (Polkinghorne, 1995). Her konuşma ve metin anlatı değildir. Çoğu zaman karşılıklı iletişimde ayrıntılı bir olay örgüsünün, karakterlerin ve bir ortamın yansıtılması gerekmez (Riessman, 1993). Bu yüzden de anlatıyı, diğer söylem biçimlerinden ayıran şey, ardışıkıı (sequence) ve sonuç (consequence) içermesidir. Buna göre, olaylar belirli bir dinleyici kitlesi için anlamlı olacak şekilde seçilir, organize edilir, bağlantılandırıır ve değerlendirilir (Hinchman ve Hinchman, 1997; Riessman, 2004; Riessman ve Quinney, 2005). Yani dinleyici kitlesinin bireysel, sosyal ve kültürel koşullarına göre de anlatı şekillenir. Burada Uzun (2015)'un ifade ettiği üzere bireylerin kişisel anlatılarını, egemen grubun ideolojisi tarafından şekillendirilen meta anlatılara katkıda bulunacak şekilde hegemonik anlatı biçiminde ifade etme eğilimi görülmelidir. Çünkü meta anlatının tahakküm gücü, bireyin anlatısında kendini göstermektedir.

Günlük kullanımda hikaye (story) ve anlatı (narrative) çokça kullanılmaktadır. Ancak anlatının ve hikayenin farklı şeyler olduğuna dikkat çekilmelidir. Örneğin "Herkesin bir hikayesi var" cümlesinin popüler kültürde de kullanılan yükselen bir trend olduğu, insanların hikayelerini paylaştıkları televizyon programlarında dahi görülmektedir. Anlatı araştırmacısı için buralarda aktarılan hikayelerde eksik olan şey, Riessman ve Quinney'nin de ifade ettiği gibi, gerçeklerin bu şekilde nasıl bir araya getirildiğine dair analitik bir bakıştır. Birey anlatısını kimin için, nasıl ve ne amaçla yapılandırmıştır? Anlatıyı yapılandırmasında hangi kültürel kaynaklara başvurmuştur? Birey anlatısıyla neye ulaşmaya çalışıyor? Hikayede alternatif karşıt anlatıları önerebilecek boşluklar ve tutarsızlıklar var mı? Popüler kullanımda bir "hikaye", derinleşmiş bilgi için savunulabilir bir pozisyon olan yorumlama gerektirmeyen bireyin kendisi için konuşması olarak görülmektedir (Riessman ve Quinney, 2005).

Ancak anlatı araştırmasında hikaye, insan hayatının bir bölümünü, yer ve zaman kavramına bağlayarak ele alır. Dolayısıyla kişilerin anlatılarının zamansal açıdan başlangıcı, ortası ve sonu olan düzenlenmiş anlatı etkinliklerinden hikaye oluşur. Anlatılar insan deneyiminin sadece bir kısmına yer verir ve hikayeler anlatılara dayanır (Kim, 2016: 8). Kişisel hikayeler, yalnızca bir kişiye hayatının hikayesini anlatmanın bir yolu değildir; kimliklerin modellendiği araçlardır (Rosenwald ve 
Ochberg, 1992b akt: Riessman, 1993). Hikayeler, eylemlerin ve olayların, amaçlara ulaşmak ve amaçları gerçekleştirmek için olumlu ve olumsuz katkıda bulunduğu insan deneyimini benzersiz biçimde tanımlayan bir bilgi türünü ifade eder. Bir başka deyişle insan eylemlerini ve deneyimlerini, yaşam olaylarının değişikliklerini ve mücadelelerini ve kişilerin eylemlerinin farklıı̆ıını ve karmaşıklığını anlamak için hikayeler kullanılır. Zaman ve mekân içinde gelişen deneyimi bulmak için deneyimlerin hikayesinin içerisine olaylar koymaya çalışılır. Tüm bunlarla bireylerin duygularını, hedeflerini, algılarını ve değerlerini içererek insan deneyimlerini anlamaya yönelik bilgi sunulur (Polkinghorne, 1995). Anlatı, zaman ve mekânı aşan bir zaman makinesi içerisindedir. Herhangi bir hayat hikayesi kesişen bir dizi anlatının bir parçasıdır (Macintyre, 2007: 218 akt: Kim, 2016: 8).

Burada öykü ve hikaye kavramının farkının da açıklanması önemlidir. Her ne kadar birçok kaynakta birbirinin yerine geçen şekilde kullanılsa da aslında öykü ile hikayenin tanımı farklıdır. Soyşekerci (2014)'nin de belirttiği gibi öyküde yaşama dair birdenbire başlayan ve biten bir kesit sunulur yani öykünün öncesi ve sonrasına yer verilmez. Öyküde söylenmeyen, yazılmayan, aktarılmayan boşluklar vardır ve boşlukları anlamlandırmak ve yeniden yazma konusu okuyucuya bırakılır. Ek olarak nedensellik yerine, sorunların karmaşık yumağının anlatımı ön plana geçer (Soyşekerci, 2014). Bu tanımdan da anlaşılacağı üzere anlatı araştırmasında, anlatılardaki zamansal boşluklar doldurularak başlangıcı, ortası ve sonuna yer verilerek hikaye oluşturulduğu için hikaye kavramı daha doğrudur.

Kavramlar arasındaki bu farklılıkları özetleyebilmek için şu noktalara dikkat çekilmelidir. Anlatı, bireyin sosyal bağlam üzerinde vurgulanmış halidir. İnsanların hayatları devam eden deneyimsel bir süreçtir ve hayal edilmiş bir geleceğe doğru ilerleme meselesidir. Bu yüzden de insanlar hikayelerini yeniden ve yeniden anlatır. Kişi hikayeleri aynı anda yaşar, anlatır ve tekrar anlatır ve yeniden yaşar (Connelly ve Clandinin, 1990). Bir başka ifadeyle anlatılar, algısal deneyimi yapılandırır, hafızayı düzenler, yaşam olayını parçalar ve amaç inşa eder (Bruner, 1987:15 akt: Riessman, 1993) ve buradan da hikayeler yeniden yeniden oluşur. Eğer gerçekten birinin hikayesini anlamak istiyorsak, hikayede etkili olan ve aslında anlatılarını şekillendiren tarihsel, politik, çevresel, kişisel faktörleri ve hikayeye dahil olan herkesi keşfetmek gerekir (Kim, 2016: 236). 


\section{Anlatı Araştırması}

Anlatı yaklaşımının felsefi temeli daha öncede belirtildiği gibi postmodernizm, sosyal inşacılık, yapılandırılmacılık ve feminizme dayanır. Bunlardan postmodernizmin anlatı araştırmasına yansımasında temel bilgilere ve ayrıcalıklı söylemlere (büyük anlatılara) ilişkin tek bir doğru, kesinlik ve nesnel gerçeklik olmadığı tezi vardır. Sosyal inşacılık teorisinde gerçekliğin toplumda sosyal olarak üretilen bir meta olduğu bilgisi vardır. Toplumda üretilen sosyal gerçekliğe göre bireyler kendi dünyalarını inşa ettiği için ve tarihin, bağlamın, kültürün, dilin, deneyimin ve anlayışların gömülü olduğu sosyal yapı gözetilmeksizin bireyin gerçekliğini nasıl kurguladığı anlaşılamaz. Bireyin gerçekliği elbette geçmiş yaşantısının bugüne olan yansıması anlatı yoluyla nasıl aktardığı ile anlaşılabilir ve anlam kazanır (Baldwin, 2013). Anlatı yaklaşımının felsefi temelindeki yapılandırmacılık ise, gerçekliğin bireyin kendi yarattığı bir ürün olduğu fikrine dayanır. Her birey, dünyayı ve deneyimlerini kişisel inanç sistemleri yoluyla görür ve yorumlar. Dolayısıyla anlatı araştırması, bireylerin bu inanç sistemleri içinde kendilerini, kimliklerini şekillendiren tutumlarını, değerlerini ve fikirlerini görmemize ve nasıl bir anlam inşa ettiklerini duymamıza olanak tanır. Feminizmin ise araştırma ilişkilerini danışmanlık ve işbirliği olarak görmesi; araştırmadaki güç ilişkisi meselesini ele alarak eşitliği sağlamaya çalışması; özellikle de ötekileştirilen grupların seslerini duyurma konusunda bir platform sunarak güç ve özerklik yaratmaya yardımcı olması; düşünümsellikle bildiklerimizi nasıl keşfedeceğimiz konusunda şeffaflık sunması ve katılımcılarla elde edilen bilgilerin sahipliğini paylaşarak hakim anlayıştaki profesyonellerin uzman olduğu varsayımını sorgulamaya başlaması bakımından anlatı araştırmasında önemli bir yeri verdir (Etherington, 2011). Bu felsefi temellere bakarak anlatı araştırmaları şöyle tanımlanabilir: Anlatı araştırmaları, klasik doğru, gerçeklik, anlam ve bilgi kavramlarından şüphe duyar. Anlatılarda ve hikayelerde ortaya çıkan güç ilişkilerini sorgulamayı amaçlayarak, meta-anlatıyı ya da evrensel gerçeği reddetmek için birden fazla gerçekle ilgili karmaşık ayrıntıları ele alır (Kim, 2016).

Anlatı araştırması, insanın eylemini tanımlamak için kullanılan hikayeler içinde nitel araştırma tasarımlarının bir alt kümesini ifade eder (Polkinghorne, 1995). Ancak çoğu nitel görüşmede, konuşmanın çoğu anlatı değil, soru-cevap alışverişi, argüman ve diğer tartışma biçimindedir (Riessman, 2002). Çünkü anlatı, bireyin deneyimlerini ortaya koyan bir başlangıç, orta ve bir sonu olan bir hikaye olarak tanımlandığı zaman birçok şekil alır (Manning ve Cullum-Swan, 1994 akt: Larsson ve Sjöblom, 2010). Buradan yola çıkarak anlatı araştırmasını, deneyim ve anlatıları araştıran 
hikaye anlatımı metodolojisi olarak tanımlamak (Kim, 2016:106), nitel araştırma görüşmesinden farkını ifade etmek açısından yardımcıdır.

Anlatı araştırması literatüründe, anlatı yöntemleri genellikle bireylerin farklı kimliklerini veya içsel benliklerini nasıl deneyimlediklerine erişim sağlamak için stratejiler olarak tanımlanır (Larsson ve Sjöblom, 2010). Dolayısıyla anlatı araştırmasında araştırmacı ve katılımcılar arasındaki işbirliği vasıtasıyla, zamansallık, yer ve sosyal çevreyle sosyal etkileşim içinde deneyimleri anlamanın ve araştırmanın bir yolunu sunar. Anlatıyı toplamanın ise birçok aracı vardır. Bunlar; saha notları, günlükler, görüşmeler, hikaye anlatımı (storytelling), mektup yazma, özgeçmiş ve biyografik yazı gibi araçlara yer verilmektedir. Bu yüzden de Connelly ve Clandinin (1990: 20) "anlatı araştırmasının" adına "anlatı içerisinde araştırma" denmesinin daha doğru olduğunu ifade ederek anlatının hem bir fenomen hem de bir yöntem anlamına geldiğini vurgularlar (Clandinin ve Connelly, 2000).

Anlatı araştırmasının boyutlarını belirten ve kavramsal çerçeve olarak yer alan "zamansallık, toplumsallık ve yer" vurgusu, anlatı araştırmasını diğer araştırmalardan ayıran özelliktir. Bu üç vurgu üzerinde durarak araştırmacı, katılımcının deneyimlerinde yarattığı ilişkisel yansımaları araştırır (Clandinin ve Huber, 2010). Connelly ve Clandinin (2006: 481) anlatı araştırmasında, anlatıyı düşünebilmeyi öğrenmek için anlatı araştırmasının tasarımının önemini vurgulamış ve dikkate alınması gereken çeşitli unsurları belirlemişlerdir:

1. Yaşam alanını düşleme/görüntüleme: Bir anlatı araştırması tasarlamak "bir hayal gücü eylemini" içerir. Araştırmanın yapılacağı yeri, katılımcının yaşadığı yeri, deneyimin yaşandığı yerin neresi olduğuna dair yaşam alanını hayal etmeliyiz. Böylece, bir anlatı araştırması tasarımı, alan içerisinde olan her şeyin kişisel olarak da farkında olmayı planlamaktır.

2. Saha metinlerini toplamada başlangıç noktası olarak yaşama ve anlatma: Anlatı olarak düşünme geçmişte yaşanmış olanları hayal etmeyi (anlatma) ve gözler önüne serildiği gibi başkasının yaşam rolünü ezberleyerek yaşamayı (yaşama) içerir. Anlatma görüşmeler, röportajlar, kişisel günlük, fotoğraflar, eserler, konuşmalar vb. yollarla toplanır ve yaşama ise, gözlem ve/veya katılımcı gözlemleri yoluyla araştırma alanındaki yaşam yoluyla kazanılır. Dolayısıyla, anlatı araştırması, yaşamak, anlatmak, tekrar anlatmak ve tekrar yaşamak gibi dört eylemi içerir. 
3. Vurguların tanımlanması ve dengelenmesi (zamansalık, toplumsallık ve yer): Yaşam alanının hayal edebilmek için anlatı araştırmasının vurgularını göz önüne almalıyız.

- Zamansallık: Anlatı araştırması bir olayın veya bir kişinin zamansal açıdan dönüştüğünü kabul eder. Bu yüzden bir olayı ya da bir kişiyi geçmiş, şimdiki zamanda ve mümkünse geleceği de yansıtılmasıyla ilişki içinde tanımlanır. Genel olarak, geçmişin önem taşıdığı, şimdiki zamanın değer taşıdığı ve geleceğinde niyeti ifade ettiği belirtilmektedir.

- Toplumsallık: Anlatı araştırması, katıımcı ve/veya anlatıcının kişisel ve toplumsal koşullarıyla da ilgilenir. Toplumsallık, anlatı araştırmasının çoğunlukla bir kişinin düşüncelerine ve duygularına odaklanılmasını veya çoğunlukla kişiliksiz hale getirilen toplumsal koşullara odaklanılmasını engeller.

- Yer: Eylemin gerçekleştiği, karakterlerin oluştuğu ve hikayelerini yaşadığı ve kültürel ve sosyal bağlamın rolleri kısıtladığı ve etkinleştirdiği yerdir. Anlatı araştırmasında örneğin okul, ev, topluluk veya çevre gibi çalışmaya etkisi olan yerlerin çeşitli yönlerini görmeyi gerektirir. Bir anlatı araştırmacısının her yeri etkisiyle birlikte düşünmesi gereklidir.

4. Araştırmada kendine yatırım: Bir anlatı araştırmasını tasarlarken pişirme kazanı olarak kendimize yatırım yaparak sahadaki yaşanmış verileri toplamak gerekir. Bunu yaparken araştırmacı, katılımcıların yaşamlarıyla kendisini iç içe geçmiş bir durumda bulabilir ki, bu durum veri toplamayı etkiler, katılımcılarla ilişkiyi ve araştırma metnini de etkiler.

Anlatı araştırmasını felsefi temellerini ve anlatı araştırmasının öne çıkan temel noktalarını tanımladıktan sonra, anlatı araştırmasına dair bazı sınırlılıklar, eleştiriler ve zorluklardan da bahsedilmelidir. Anlatı araştırmasının yöntemine dair literatürde yer alan sınırılıklar ve eleştiriler; analizdeki zaman taahhüdünün çok sayıda katıımcıyı içeren araştırmalarda kullanılmasını zorlaştırması, katılımcılarla yakın ilişki kurulması ve araştırmacının bir analizdeki rolü dolayısıyla katılımcı olarak görülmesi, katılımcılarla kurulan ilişkiden dolayı araştırma sürecini sonlandırma konusunda yaşanan güçlük, araştırmacının katılımcının hikayelerini daha geniş anlatılar içerisine yerleştirmesinin katılımcının yaşadığı deneyimi etkilemesi, araştırmacının süregelen anlatı yapılarını paylaşmasının hikayenin yeniden 
anlatılması üzerindeki etkisi (Josselson, 1996), analizinde birleşik yöntemlerin eksik olması dolayısıyla yöntemlerin uygulanmasındaki zayıflığın sonuçların güvenirliliğini etkilemesi,) hikayelerin doğası gereği belirsiz ve yoruma açık olması nedeniyle araştırmacının öznelliğinin bu yaklaşımda özel bir etkisinin olması (Peshkin, 1988) gibi sıralanabilir.

Anlatı araştırmasının zorluklarını ise Creswell (2013) işlem basamakları ve karakteristik özellikleri dolayısıyla tanımlamıştır. Bunlar; katılımcı ile ilgili yoğun veri toplanmasının gerekmesi, katılımcının içinde yaşadığı ortamın çok iyi anlaşılmasının gerekliliği, belirli hikayeleri bir araya getiren ana kaynakları belirlemenin farklı bakış açılarına sahip bir anlayışı ve keskin bir gözü gerektirmesi, katılımcılarla aktif işbirliğinin gerekliliği, araştırmacının katılımcıların hikayelerini tartışması ve sonrasında bunu kendi kişisel ve siyasi arka planlarına dair belirleyici noktalarla nasıl yeniden hikayeleştirdiğini yansıtması gibi sıralanabilir. Burada yer verilen anlatı araştırmasına dair bahsedilen bu sınırlılıklar, eleştiriler ve zorluklar, anlatı araştırmasının görüşme ve analiz sürecine dair bilgilerin ele alındığı diğer başlıklar okunduğunda daha iyi anlaşılacaktır.

\section{Anlatı Araştırmasında Görüşme Süreci ve Hayat Hikayesini Oluşturma}

Anlatıları hikayeye dönüştürme noktasında araştırmacı önemli bir konumdadır. Anlatıların bir olay örgüsü içerisinde düzenlenmesi, araştırmacı tarafından yapılmaktadır.

Olay örgüsü, bireysel olayların içeriksel anlamının görüntülenebileceği bir kavramsal düzen şemasıdır. Hikayelerde geçmişten günümüze ve geleceğe doğru olaylar, yorumlamalar, motivasyonların ve yaşadığımız şeylerin sonuçlarının etkili olduğu dolayısıyla olay örgüsü kurulurken olayları nedensel olarak bağlantılandırarak etkiye dönüştürme yoluyla ilişkilendirme yapılır. Olay örgüsü, olayları bir hikayede oluşturmak ya da yapılandırmak için çeşitli işlevleri içerir. Bunlar: (a) hikayenin başlangıcını ve bitişini işaret eden geçici bir aralığın sınırlandırılması, (b) hikayeye dahil edilecek etkili olayların seçimi için kriterler sağlanması, (c) olayların belirli bir sonuca katkısını gözler önüne serme hareketi içerisinde zamanla düzenlenmesi ve (d) olayların birleşik bir bütün olarak hikayeye katkı sağlayıcı olarak sahip olduğu anlamları açıkığa kavuşturulması veya açıklanması (Polkinghorne, 1995).

Görüşme esnasında olay örgüsünü sağlayacak nitelikte sorular sorabilmek için anlatı araştırmasında görüşmelerde çok fazla yapılandırılmış bir soru kağıdının kullanılmadığı, çoğunlukla yarı yapılandırılmış formlarla görüşmelerin yapıldığı 
belirtilmektedir. Bunun sebebi, bireylerin anlatılarının kendi dünyalarında şekillendiği gibi kaydedilmesinin önem verilmesi ve bunu yaparken de bireyin anlattıklarını olay örgüsü içerisinde hikayeleştirebilmek için uygun yerde gerekli soruların sorulmasına esneklik imkanı tanımasıdır. Görüşme soruları entelektüel olarak merak, esneklik, açık fikirlilik ve araştırma süreçlerine uyumun bir parçası olarak oluşturulur ve sezgi ve beklenti için bir alan açar (Kim, 2016: 97).

Etherington ve Bridges (2011) anlatı araştırmacısının merakı ıir şekilde, bilmeyen pozisyonundan ('curious, not knowing' position) başlayarak, anlatıcının sosyal ve kültürel bağlamı ele almasına yardımcı olan sorulara odaklandığını belirtmiştir. Burada özellikle olaylar karşısında bireyin hislerine, duygularına, düşüncelerine tutumlarına, fikirlerine; diğer insanların önemine; anlatıcının değerler, inançlar ve amaçlar temelinde seçimlerine ve eylemlerine; tarihsel sürekliliğe ve deneyimlerin temsil eden metaforlar, semboller ve yaratıcı ve sezgisel bilme yolları üzerinde bağlamı yakalamasına yönelik sorular sorulmaktadır (Etherington ve Bridges, 2011: 12). Etherington (2011) anlatı araştırmasında bireyin hikayesini olay örgüsüne oturtabilmek ve sosyal ve kültürel bağlamı yakalayabilmesine yardımcı olmak için araştırmada sorulması gereken soruları örneklendirmiştir. Bunlar;

- "Bana ... deneyimlerinizi anlatabilir misiniz?" yerine “...... olduğu zaman neler yaşadığınızı anlatabilir misiniz?”, diğer karakterleri hikayeye davet etme sorusu: "Kiminle birlikteydin?" "O zaman ne oldu?", hikayelerin zamansal doğasını çağırma sorusu: "Bu ne kadar sürdü?", anlamlandırmayı ifade etme sorusu: "Bütün bunlardan ne tür anlamlar çıkardın?", dönüm noktasını bulma sorusu: "Bunun devam edemeyeceğini ne zaman anladın?"

- Sosyal ve kültürel bağlamsallığın (değerlerin, inançların, alışkanlıkların vb. ayrıntıların) keşfedilmesine dair sorular: Bunu nasıl biliyorsun? Bunun neden olduğunu düşünüyorsun? Bunun hakkında ne düşünüyorsun? Bu genellikle yaptığın bir şey miydi? Bu senin için uygun muydu?

- Anlatıcının olaylar karşısındaki duyularının, duygularının, düşüncelerinin, tutumlarının ve fikirlerinin şekillendirilmesinin ve ilişkilendirmesinin doğasına dair sorular: Neyi görebilirdiniz / duyabildiniz?, Sana nasıl geldi? Neler olup bittiğine dair anlayışınız neydi? Bununla nasıl başa çıktın? Seni nasıl etkiledi? Sana nasıl hissettirdi? Bu durum hakkında ne düşündünüz? Bu yaptığı hakkında ne düşünüyorsun? 
- Diğer kişilerin önemine dair sorular: Anlatıcının ilişkiler ağı olayları nasıl etkiliyor? Diğer karakterler kimlerdi? Ailen bu konuda ne düşündü? Birilerinden yardım istedin mi? Neler olup bittiğinin farkında olan başka biri var mıydı? Arkadaşlarınız neredeydi?

- Anlatıcının değerleri, inançları ve amaçları temel alan seçimleri ve eylemlerine dair sorular: Neden oraya gitmeye karar verdin? Niçin bunu yapmak istiyorsun? Ne yapmayı düşünüyorsun? Ne olmasını istiyorsun? $\mathrm{Ne}$ zaman buna karar verdin?

- Anlatıcının bir yerden (bağlamsal bilgi) geldiğini ve bir yere gideceğini anlamak için tarihsel sürekliliğe dair sorular: $O$ zaman hayatının geri kalanında neler oluyordu? Hangi yıldı? Bu olduğunda kaç yaşındaydın? O zaman okula gidiyor muydun? Sonunda oraya gittin mi?

- Olay örgüsünü tamamlamak için hikayenin başlangıcı, ortası ve sonuna dair sorular: Hikayen nerede başlıyor? Bu duruma nasıl geldin? Bundan sonra ne oldu? Sen ne zaman güvende olduğunu fark ettin? Şu anda ne düşünüyorsun?

- Metaforlar, semboller ve yaratıcı, sezgisel bilme yollarına dair sorular: Bu ne gibiydi? ‘Bu bir çukur içine düşmeye benziyordu' dedin. Bu konuyu biraz daha açabilir misin? (Etherington, 2011).

Anlatı araştırmasının özü, araştırmacı ile katılımcı arasındaki ilişkide yatmaktadır; bir başka deyişle anlatı araştırması ilişkisel bir süreçtir (Clandinin ve Connelly, 2000). Görüşme sürecinde hem katılımcının hem de görüşmecinin dayanışması hakimdir; çünkü her ikisi de katılımcının hayatının önemli yönlerini savunmaya çalışıyorlardır (Kim, 2016: 169). Araştırmacıya hikayesini anlatan kişi, bir dizi olayı sadece basit bir şekilde anlatmakla kalmaz, aynı zamanda hikayenin nasıl geliştiği hakkında bilgi verir. Araştırmacı ve katııımcı, anlatısal bir ortak yapım yapıyormuş gibi görülebilir, yani etkileşim süreci boyunca gelişen bir hikaye üretecek biçimde bir diyalog alışverişinde bulunurlar (Riessman, 2002, 2003). Yukarıda örnek verilen sorulara bakıldığında bu diyalog içerisinde hikayenin nasıl geliştiği görülecektir.

Görüşme esnasında araştırmacı ile görüşülen kişinin arasındaki etkileşim dolayısıyla hikaye farklı bir biçim alabilmektedir de (Reissman, 1993). Çünkü sorulan sorularla, birey belki daha önce hiç düşünmediği konular ya da gözden kaçırdığı kişiler hakkındaki soruları cevaplarken daha önce anlattığından başka bir biçimde hikayesini anlatabilir. Bu duruma ilişkin kendi anlatı araştırması sırasında Kim (2005: 
57-58) sanki katılımcıları tarafından tasarlanmış hikayeleri yayınlamaya çalışan bir "ebe" gibi hikayenin doğumuna yardımcı pozisyonunda hareket ediyormuş gibi hissettiğini belirtmiştir.

Bir sonraki aşama olan görüşmelerden sonra görüşmelerin yazıya dökülmesi yani deşifre işleminde ise çok ayrıntılı bir deşifrenin yapılmasının önemli olduğu belirtilmektedir. Nitel araştırmalarda da ayrıntılı transkripsiyonların nasıl olması gerektiği üzerinde durulmaktadır: "Sessizlikleri, yanlış başlangıçları, vurguları, "uhm" gibi sözcüksel olmayan sesleri, konuşmalarını "öyle" veya "böyle" gibi söylem belirteçlerini ve anlatıya dinleyici katıımının diğer işaretlerini eklemeleri gerekir mi?" (Reissman, 1993) Bilinmektedir ki, sessizlikler, molalar, kahkaha, mizah, duraklamalar, yanlış başlangıçlar ve anlatılardaki belirsizlikler, çok sesliliği ve karşıt anlatıların ortaya çıkışını temsil edebilir (Riessman ve Quinney, 2005; McKenzieMohr ve Lafrance, 2014; Fraser ve MacDougall, 2017). Bu yüzden de görüşme sürecinde görüşülen kişinin gözlemlenen mimikleri, nefes almaları, heyecanlanmaları, yanlış başlangıçları gibi tepkilerine yer verilmesi anlatı araştırması için önemli bir bilgi sağlamaktadır.

Görüşmeler yapıldıktan sonra anlatı araştırmasının yazma aşamasında Connelly ve Clandinin (1990), araştırmacının rolüne dair önemli bir diğer noktaya işaret etmişlerdir. Yazma aşaması araştırmacıya elde edilen anlatıları genişletme (broadening), derine inme (burrowing) ve yeniden yapılandırma (restroying) olmak üzere 3 analitik araç sunmaktadır. Genişletme ile anlatıda katıımcının değerlerine, karakterine ya da bulunduğu sosyal, kültürel ve tarihsel çevrenin de dahil edildiği daha geniş çerçeveden bakma durumu ifade edilir. İkinci olarak derine inme aşamasında araştırmacı, katılımcıların duygularına, yaşadığı anlaşmazlıklara, ikilemlere, yaşanılan olayın ve çevrenin katılımcı üzerindeki etkisi üzerinde durarak bunların deneyimleri neden ve nasıl etkilediği üzerinde durur. Araştırmacı anlatılara geniş ve derin bir çerçeveden baktıktan sonra ise anlatıları hikayeleştirme, yani yeniden yapılandırma sürecine geçer ve bu noktada katıımcının hikayesinde öne çıkan deneyimler belirginleşmiştir (Kim, 2016: 207). Spence (1986) görüşmeler esnasında katılımcının anlatmadığı ancak hikayeleştirme sırasında olay örgüsü kurulurken anlatıyı düzeltme işlemi yapılması ile belirsiz anlatının araştırmacı tarafından dengelenmeye çalışılmasını yargısal bir konu olarak görmüştür. Yapılan bu işleme de "anlatı düzeltme-narrative smoothing" adını vermiştir. Bu, araştırmacının okuyucuya bir kapı açma ve anlatılanların yanında anlatılmayanlara karşı da dikkatli olması meselesidir (akt: Connelly ve Clandinin, 1990). 
Yazma aşamasında anlatının düzenlenmesi ve yorumlanmasında Riessman (2002) araştırmacının dil üzerine yoğunlaşması gerektiğini vurgulamıştır. Riessman (2002) 'a göre, anlatının anlamlandırılması kullanılan dil vasıtasıyla olmaktadır ve kullanılan dil anlatının yorumlanmasını da etkilemektedir. Bu çerçevede anlatının anlamında dilin üç analitik işlevi vardır. Bunlar içeriği ifade eden düşünsel işlev, konuşmacılar arasındaki rol ve ilişkiler ile ilgili kişilerarası işlev ve yapıyı yansıtan metinsel işlevler, yani metnin bölümlerinin sözdizimsel ve anlamsal olarak nasıl bağlandığıdır. Anlam bu birkaç farklı seviyeden aktarılır. Birinin söylediği (düşünsel), bir şeyin nasıl söylendiği (metinsel) ve kime söylendiği (kişilerarası) ile bağlantılıdır. Bu sosyal bağlam, anlatının anlamını anlama sürecinde çok önemlidir (Riessman, 2002).

Araştırmacının konumu noktasında Connelly ve Clandinin, (1990) anlatıları yazarken araştırmacıyı "birden fazla benin" bulunduğu bir durumda ifade etmişlerdir. Yani anlatıyı yazarken hem bir araştırmacı hem bir kadın hem bir yorumcu hem de bir araştırma katılımcısı olarak çok sesli olarak ifade etmiştir. Bunun yanında Peshkin (1985 akt: Connelly ve Clandinin, 1990) araştırma alanında bizim de sadece bir araştırmacı olarak orada bulunmadığımızı, politik, ekonomik ve sosyal koşullar altında bir insan olarak orada bulunduğumuzu ifade eder. Riessman (2002) bir araştırmacının tarafsız ve nesnel olmasının ve insanların neyle ilişkili olduklarını rapor etmenin imkânsız olduğunu belirtmektedir. Öte yandan araştırmacının, üzerinde çalıştığı kişisel deneyimlere doğrudan erişimi yoktur. Ancak araştırma süreci, incelenmekte olan temel deneyimlerin farklı temsil seviyelerini içermektedir. (Larsson ve Sjöblom, 2010). Bu noktada anlatı araştırmacısının bu araştırmayı yapmadaki kişisel, uygulamaya dönük ve sosyal gerekçelerini yazması önemlidir. İlk olarak kişisel gerekçelendirmede "araştırmacının kendi deneyimleri, gerginlikleri ve kişisel araştırma bulmacası bağlamında araştırmayı gerekçelendirmesi olarak açıklanmaktadır. Uygulamaya dönük gerekçelendirmede araştırmacının, uygulamayı değiştirme veya dönüştürme olasılığını değerlendirmenin önemine dikkat çekilir. Sosyal gerekçelendirmede ise "çalışmayı yapınca ne olacağı ve kimin önemsediği" konusu üzerinde durulur. Burada teorik gerekçelendirme sosyal eylem ve politikaya dair gerekçelendirme olarak iki şekilde düşünülmektedir. Teorik gerekçe metodolojik açıdan ve disiplin bilgisi açısından doğrulamayı gerektirir. Sosyal eylem ve politika konusunda ise toplumun belli bir kesimine yönelik bir durumun etkilerini gözler önüne sermeyi ifade eder (Clandinin ve Huber, 2010). Anlatı araştırmasında araştırmacının "Bu konuda çalışmaya karar verdim çünkü...." ile başlayan cümleyi, kendisinin bu çalışmayı yapma nedenini, kişisel yaşantısındaki 
bu araştırmanın yeri, uygulamada gerçekleştirmek istediğinin ne olduğu ve sosyal anlamda bu çalışmayı yapmasının ne gibi çıktıları olacağı bağlamında yazması önemlidir. Burada araştırmacının konu ile bağlantısının anlaşııması da sağlanacaktır.

\section{Anlatı Araştırmasında Analiz}

Anlatı analizinde öncelikle anlatıların olay örgüsüyle zamana dayalı tutarlı bir bütün halinde düzenlenmesi sonucu hikayelerin oluşturulması gereklidir. Bu hikayelerin çözümlenmesi için ise öncelikle olaylar ve eylemler arasındaki boşlukları doldurmada "anlatı düzeltme" yönteminin kullanılması gereklidir. Bunun nasıl yapılacağına bir önceki bölümde yer verilmiştir. Bu sayede okuyucunun, hikayelerde anlatıların neden ve nasıl olduğunu ve katılımcıların neden ve ne şekilde eylemlerde bulunduklarını anlamalarına yardımcı olmaya çalışılır. Kim (2016)'in belirttiği gibi anlatı analizi ile yapılandırılan son hikaye ile okuyuculara, başkasının yaşadığı deneyimlerle anlaşılabilir bir insan fenomeni olarak empati kurmalarına yardımcı olacak bir şekilde hitap edilmesine çalışılır.

Anlatı araştırması, insanların hikayelerini kendileri tarafından söylendiği gibi yer verirken, geleneksel, modernist bir bakış açısıyla doğru, gerçeklik, bilgi ve kişilik görüşlerine meydan okuyarak bu hikayelerin sistematik olarak toplanması, analiz edilmesi ve temsil edilmesi için bir araçtır (Etherington, 2011). Bunun Polkinghorne (1995: 15)'nun anlatı analizi bağlamında araştırmacının basamaklarını Kim (2016: 197-198) şu şekilde özetlemiştir:

- Etkinliklere, eylemlere, olaylara ve diğer veri öğelerine bunları bir olay örgüsü içinde bir araya getirmeye odaklanır;

- Parçadan bütüne veya bütünden parçaya doğru ileri ve geri yineleyen hareket kullanır;

- Anlatı düzeltme işlemini kullanarak olaylar ve eylemler arasındaki boşlukları doldurur;

- Bağlantısız veri öğelerinin aralığını okuyucunun tutarlı görebileceği bir şekilde yapar;

- Son hikayeyi veriyle uyumlu hale getirirken, verilerin kendisinde açık olmayan anlatı anlamlarını getirir;

- Anlamı vurgular ve bir hikayenin metaforik zenginliklerini sürdürür.

Anlatı analizinin birçok farklı biçimi vardır. Bunlardan bazıları anlatıların içeriğine, bazıları anlamına, bazıları ise hem anlamına hem içeriğine odaklanır. $\mathrm{Bu}$ 
araştırmadaki felsefi konumlanışa bağlıdır (Etherington, 2011). Polkinghorne (1995) anlatıların analizi ve anlatı analizi olmak üzere analizdeki iki temel yaklaşım farkından bahsetmiştir. Anlatıların analizinde, hikayeler, bilinebilir bir gerçekliğe açılan bir pencere olarak görülebilir. Bu hikayeler teoriden türetilen kavramlar kullanılarak analiz edilebilir. Bu analiz örneğin tematik analiz veya gömülü teorideki (grounded theory) verilerden türetilen kavramlarla ortaya çıkarılabilir. Ya da hikayeler, deneyimlenen yaşamın dağınıklığına, farklılıklarına, derinliğine ve dokusuna değer veren sosyal olarak konumlandırılmış bilgi yapıları olarak görülerek anlatı analizi yapılabilir (Polkinghorne 1995; Etherington, 2011).

Reissman (2005) bir çalışmasında anlatı analizi çeşitlerini 4 başlık altında tematik analiz, yapısal analiz, etkileşimsel analiz ve edimsel analiz olarak sınıflandırmıştır. Bu kapsamda tematik analiz (thematic analysis) sınıflandırması Polkinghorne (1995) 'un da geliştirdiği iki yoldan biri olan anlatıların paradigmatik analizi bu çerçevede değerlendirilebilir. Anlatıların paradigmatik analizi ve anlatı analizi olmak üzere iki farklı yolu geliştiren Polkinghorne (1995) paradigmatik analizi şu şekilde ifade etmiştir. Birincisi anlatıların analizi olarak da açıklanabilen paradigmatik analiz anlatıları ya da hikayeleri veri olarak içeren hikayeler arasında ortak temaları veya kavramsal bulguları belirlemeye çalışarak analizlerinde yineleyici bir hareketi vurgulayan paradigma tipolojileri ya da kategoriler üreten çalışmalardır. $\mathrm{Bu}$ kategoriler ve sınıflandırmalarda deneyimlerin aslında ısmarlama olarak oluşturulduğu ve ortak ögelerin vurgulanmasıyla da tanıdık deneyimler inşa edilmesine olanak veren kavramlarla bilişsel ağları oluşturulduğu üzerinde durulur. Paradigmatik bilgi, bir kavram olarak adlandırılan tek tek kelimelerle korunurken, anlatılan bilgiler hikayelerde de muhafaza edilir. Paradigmatik bilgi, eylemler arasında neyin ortak olduğuna odaklanırken, anlatı bilgisi her eylemin özel ve öznel niteliklerine odaklanır. Verilerin paradigmatik analizini kullanması, diğer nitel araştırmalara benzerdir ve pek çok nitel araştırma çalışması, paradigma türü bir analiz kullanmaktadır. Çoğu zaman bu yaklaşım tek bir hikaye değil, birkaç hikayeden oluşan bir veri tabanı gerektirir. Araştırmacı, aralarında hangi kavramların göründüğünü keşfetmek için farklı öyküleri inceler. İki tür paradigma araştırması mümkündür: (a) kavramların önceki teori veya mantıksal olasılıklardan türetildiği ve bu kavramların örneklerinin bulunup bulunmamasına karar vermek için verilere uygulanan; örneğin, kişilik tiplerinin örneklerini veya savunma mekanizmalarının kullanım yerlerini bulmak için psikanalitik teorinin kullanılması ve (b) kavramlardan tümevarım olarak veri türetilenler. Örneğin; önceden teorik olarak türetilen 
kavramları empoze etmek yerine, veriden kavramlar geliştiren gömülü teori gibi (Polkinghorne, 1995). Reissman (2008) tematik analizden bahsederken, önceden var olan teorinin sözlü ve yazılı anlatıların yorumlanmasını nasıl şekillendirdiğini ve bu anlatılarla bireysel ve grup kimliklerinin nasıl şekillenerek dönüştüğünü ve sosyal eylem için itici güç (örneğin otoriteye karşı direniş) oluşturduğunu Adsız Alkolikler (AA) kendine yardım destek gruplarına katılan bireyler üzerinden örnekle açıklamıştır. Reissman (2005)'ın belirttiği gibi anlatı analizinin yapılması çok sayıda kişi ile yapılan nitel yöntemle görüşmeler için uygun değildir. Çünkü anlatı analizinde, hikayenin kendisinin en ufak ayrıntısına kadar araştırma nesnesi olarak neden bu şekilde anlatıldığı ele alınır.

Yapısal analiz (structural analysis) kapsamında ise Polkinghorne (1995)'un ifade ettiği ikinci yol olan anlatı analizi verileri eylemleri, olayları ve olayları içeren ancak elde edilen anlatıları bir hikaye içerisinde olay örgüsü vasıtasıyla sentezleyip yapılandırarak analizleri hikayeler üreten çalışmalardır (ör. Biyografiler, geçmişler, vaka analizleri). Anlatı analizinde ise anlatıların analizinden ayıran bir araştırmada kullanan araştırmada sonuç, hikayeleşen bir anlatıdır. Anlatıların analizi hikayeleri ortak ögelere taşırken anlatı analizi ögelerden hikayelere taşınır. Analitik görev, araştırmacı tarafından, veri öğeleri arasındaki bağlantının, sonuçta ortaya çıkan açılmakta olan bir zamansal gelişimin parçaları olarak görüntülenmesini sağlayan bir olay örgüsü geliştirmesini veya keşfetmesini gerektirir. Araştırmacı, "Bu nasıl oldu" gibi sorularla başlar veya "Neden bu ortaya çıktı?" gibi sorulara açıklayıcı bir cevap sağlayan bir hikayenin oluşturulmasına katkıda bulunan bilgi parçaları arar. Anlatı analizi süreci, aslında, veriyi, onu oluşturan parçalara ayırmaktan ziyade sentezlemektir. Anlatı bütünleştirmesiyle oluşturulan hikaye, insanın amacı ve seçimiyle; olası olaylar, eğilimler ve çevresel baskı kavramlarının bir araya getirilmesini sağlar. Bir anlatı analizinin sonucu, geçmiş olayları bir araya getirerek nihai sonucun nasıl ortaya çıkabileceğini hesaba katarak geriye dönük olan bir açıklama oluşturur. Bu analizde, araştırmacı, öncesi-sonrası bir süreklilik boyunca verilerin olaylarını organize ederek insan deneyiminin zamansal ve gelişim boyutuna dahil olur (Polkinghorne, 1995). Polkinghorne'un kavramsallaştırması, anlatılarla çalışmanın iki farklı yolunu öneriyor: (1) veri olarak daha geniş toplumsal konuları anlamak için anlatıları kullanmak ve (2) belirli bir konunun çeşitli öğeleri yoluyla anlatı üretmek ve açıklamak.

William Labov ve meslektaşları tarafından 30 yılı aşkın bir süre önce geliştirilen muhtemelen ilk anlatı analizi metodu olan yapısal yaklaşım, kapsamlı anlatıdaki bir 
hükmün işleyişinin -gerçekleştirdiği iletişimsel çalışmayı- analiz etmektedir. Labov (1982) daha sonra kısa, konu odaklı ve zamansal olarak sıralanmış hikayeleri bir kişi üzerinden mikro analiz gerçekleştirerek ele alma yaklaşımını değiştirmiştir; ancak bir anlatı yapısının temel bileşenlerini korumuştur: Özet (hikayenin özeti ve/veya konusu) ; yönlendirme (okuyucuyu yönlendirmek için zaman, yer, karakter ve durum bağlamını sağlamak); karmaşıklaşan eylem (soruna neden olayın yer verildiği olay sırası veya olay örgüsü, genellikle bir kriz ve dönüm noktasına yer verilmesi); değerlendirme (anlatıcının, anlam üzerinde yorum yapma ve duyguyu ifade etmek için eylemden geri adım atması - anlatının "ruhu"); Çözümleme (olay örgüsünün sonucu); ve bir coda-final (hikayeyi sonlandırıp, günümüze geri getirme). Tüm hikayeler tüm öğeleri içermeyebilir ve değişen bölümlerde olabilirler. Tematik yaklaşım gibi, yapısal yaklaşımın katı bir biçimde uygulanması, tarihi, etkileşimsel ve kurumsal faktörleri dikkate almadığı için anlatıları dezavantajlı hale getirebilir (Reissman, 2005: 3).

Etkileşimsel analizde (dialogical analysis) ise vurgu, anlatıcı ve dinleyici arasındaki diyalog süreci üzerindedir. Hikaye anlatan ve soru soranın ortaklaşa konuşmaya katılmasını, tıp, sosyal hizmet ve adli süreç gibi deneyim anlatılarına sebebiyet veren belirli ortamlarda gerçekleşir. Etkileşimsel yaklaşımdan vazgeçilmeden tematik içeriğe ve anlatı yapısına dikkat edilir, ancak anlatıcıların ve dinleyicilerin iş birliğine dayalı anlam üreten birlikte inşa etme süreci olarak hikaye anlatmayla ile ilgilenilir. Kişisel deneyim hikayeleri, anlatıcının yaşam dünyasında düzenlenir ve soru sorma ve karşılıklı cevapların alışverişleri bu hikayenin içine yerleştirilir. Bu yaklaşım, konuşmanın tüm katılımcılarını içeren transkriptler gerektirir ve etkileşimin dilin ötesinde yer alan ögeleri de kapsayan özelliklerine de yer verilmesiyle güçlenir (Reissman, 2005: 4).

Edimsel analizde (performative analysis) etkileşimsel yaklaşım genişletilerek, konuşulan sözcüğün ötesine geçilerek sahne metaforunun da işaret ettiği gibi, hikaye anlatımının bir geçmişe sahip "ben" tarafından performans olarak görülmesiyle ilgilenilir - bu yaklaşımda bir kitle, dil ve jestleriyle incelenir ve "yalnız söylemekten" ziyade "yapma" üzerinde durulur. Praxis olarak dramaturjiden anlatıma uzanan performatif yaklaşım içinde değişkenliğin olduğu bir sosyal eylem şeklidir. Dolayısıyla anlatı araştırmacıları farklı özellikleri analiz edebilirler: Sözlü bir anlatıda sahne almasına izin verilen aktörler (örneğin anlatıcılar/hikayedeki başkahramanlar da dahil karakterler ve hikayedeki diğer konuşmacılar); düzenlemeler (performans koşulları ve gerçekleştirilen hikayenin düzenlemesi); 
karakterler arasındaki diyalogun hayata geçirilmesi (bildirilen konuşma); ve izleyicinin tepkisi (gösterilen dramayı yorumlayan dinleyici ve daha sonra okumaların yorumlanması). Performatif görüş, iletişim uygulamalarına yönelik çalışmalar ve kimlik yapımının ayrıntılı çalışmaları için uygundur- anlatıcıların bilinmesini ister ve kimlerin kimliklerini "yaparken" izleyiciyi içine almalarını gerektirir (Reissman, 2005:5). Reissman (2008: 124) etkileşimsel/edimsel analizin "odak gruplarını, toplulukla toplantılar ve sınıflarda yapılan çalışmaları" analiz etmek için uygun bir yöntem olduğunu öne sürmektedir.

Görüldüğü gibi anlatı analizinde birçok yol vardır. Bu makalede yer verilenin dışında da anlatı analizine dair çeşitli modellemeler bulunmaktadır. Hikayeleşen anlatının amacına uygun olarak analiz biçiminin seçimi yapılmalıdır. Anlatı analizine dair örneklemeler sunan Reissman (1993, 2005, 2008)'ın çalışmaları bu konuda önemli bir kaynaktır. Analiz konusunda hatırlanması gereken önemli bir nokta Polkinghorne (1995)'un ifade ettiği anlatıların analizi ve anlatı analizi ayırımını yapmaktır. Nitel araştırmalarda çoğunlukla yapılan tematik analizde anlatıların paradigmatik analizi yapılmaktadır. Burada yer verilen etkileşimsel, yapısal ve edimsel analizler ise daha çok sonuç olarak hikayeleşen bir anlatı olduğu için anlatı analizi kapsamına girmektedir.

\section{Meta ve Karşıt Anlatılar: Sessizleştirilen Bireyler ve Sosyal Hizmet}

Bazı deneyimler hakkında konuşmak oldukça zor gelebilir. Özellikle de toplumda kabul görmesi zor olan tecavüz, taciz, istismar gibi travmatik deneyimler hakkında konuşmak daha zordur. Bu koşullar altında bireyler deneyimlerine isim vermekte bile zorlanarak, yaşadıklarını kendilerine bile açıkça ifade etmekte zorlanabilirler. Bireyler bu deneyimleri hakkında konuşmak yerine susarak sessizliğe bürünürken, aslında olumsuz yargılardan dolayı susturulmuş, sessizleştirilmişlerdir. Anlatılar tarihsel, sosyal ve kültürel bir bağlamda geliştiği için bazı deneyimler hakkında konuşmak da buna uygun olarak şekillenmektedir. Rosenwald ve Ochberg (1992a)'ın belirttiği gibi sosyal yaşam/kültürün bireyin hikayesi aracılığıyla kendini gösterdiği için anlatı araştırmacılarının konuşmalara iyi bakması gerekir. Böylelikle anlatılardaki toplumsal cinsiyet eşitsizlikleri, ırksal ayrımcılıkları veya hafife alınan diğer iktidar biçimlerini ele almaları mümkün olur. Bireyler doğalmış gibi konuşurlar ancak kullandıkları kavramların terimlerin kültürel ve tarihsel olarak koşullu olduğunu analiz edebilmek anlatı araştırması ile mümkündür (akt: Reissman, 1993: 8). 
Anlatı metodolojileri, toplumdaki ötekileştirilen ve ikincilleştirilen grup üyelerine özellikle odaklanarak toplumda var olan güç farklılıklarını görünür kılmak konusunda araştırmacılar için işlevsel bir yol sunar (Elliot, 2008: 145 akt: Uzun, 2015: 74). Sessizleştirilen ve ötekileştirilen grupların uygun bir aracılıkla seslerini duyurmanın ve yaşadıklarına dair anlayış geliştirmenin hem anlatı araştırmasında hem de sosyal hizmet uygulamasında önemli bir yeri vardır (Riessman ve Quinney, 2005). Ancak Reissman (1993)'ın belirttiği gibi bu ses verme meselesi, anlatı araştırmasında sesin yorumlanarak duyurulması anlamına gelmektedir. Örneğin feminist araştırmalarda hayat hikayesi üzerine yoğunlaşarak susturulmuş kadın gruplarının deneyimlerindeki çeşitliliğe "ses verme" vurgusu, anlatı araştırması ile sesin yorumlanarak duyurulması anlamına gelmektedir (Reissman, 1993).

Anlatı araştırmaları, insanların yaşamlarını derinlemesine anlamak için çok umut verici bir yaklaşımdır. Bu yüzden de sosyal hizmet araştırması yapılırken anlatı yöntemleri büyük önem taşıyabilir (Riessman ve Quinney, 2005). Sosyal hizmet için anlatıların önemli bir işlevi, bireyleri ve grupları anlamayı inşa etme yeteneğidir. Kendimize anlattığımız ve bize anlatılan hikayeler, benlik duygumuzu inşa etmektedir. Kişilikteki ana akım formülasyonlarının aksine, bir anlatı perspektifi kimliği bağlam içinde akışkan, çoğul ve birlikte yaratılmış olarak kavramsallaştırır (McKenzie-Mohr ve Lafrance, 2017). Deneyimlerin, benliğin ve kimliğin anlatılarla inşa edildiği bilgisi, sosyal hizmetin değişim ve gelişim, güçlendirme ve özgürleşme gibi amaçlarına dair önemli bir işleve işaret etmektedir. Riessman (1993) ifade ettiği gibi insanlar kimlikleri ve yaşamlarının inşası için kişisel anlatılardaki geçmiş olayları ve eylemleri, neyi dahil etmeleri neyi çıkarmaları gerektiğini ve onlar için anlamlarını düşünerek düzenlerler. Bunun içinde belirli deneyimleri anlatıya dönüştürürler ve çoğunlukla da ideal ve gerçek, ben ve toplum arasında bir aykırılık bulunur (Riessman, 1993: 2-3). Bu aykırılığa dair hikayeyi oluşturma noktasında ise etkili olan noktalara bakmak gerekir. Ancak bazı hikayelerin diğerlerine göre daha fazla tahakküm gücü vardır. Bu gücü, bazı hikayelerin kültür içerisinde medyada, politika belgelerinde ve günlük konuşmada yaygın olarak kendini göstermesi ile elde edilen "meta (master) statü" ile açıklanır. Dolayısıyla tüm hikayeler toplumdaki etkilerinde eşit değildir (Frank, 2010 akt: McKenzie-Mohr ve Lafrance, 2017). Andrews (2004) meta anlatıların, insanların deneyimlerinden neyin normatif olarak kabul edildiğini tanımlamasına yol açan güçlü bir yapı olduğunu ifade eder. Ve bu yapı içerisinde meta anlatılar, içselleştirilmeyle güçlenir. Dolayısıyla meta anlatıya uygun anlatılar dile getirilerek meta anlatı yeniden üretilir ve daha da güçlendirilir. Ancak deneyimler 
bilindik meta anlatı ile eşleşmediğinde bu deneyimlerin temelleri sorgulanır ve meydan okuma orada başlar (Andrews 2004 akt: Uzun, 2015). İşte o zaman meta anlatılara uymayan karşıt anlatılar oluşur. Baskın kültürel ideolojiye uygun deneyimler hikayeleştirilirken, bu ideolojiye uymayan deneyimler ise aktarılmaz (Roche ve Wood, 2005).

Delgado (1989) araştırmasında hikayeleri incelerken, egemen grubun ideolojisi tarafından şekillenen sosyal ve yasal hikayeler karşısında insan vicdanını duyarlı hale getirmek için karşıt hikaye anlatımını önermiştir. Karşıt hikayelerin, anaakım fikirlere ve statükoya yönelik memnuniyeti sorgulama işlevi vardır. Bir başka deyişle karşıt hikayeler bireylerin baskın ideolojiye ve onu destekleyen varsayımlara itiraz etme yollarından biridir. Karşıt hikayeler, dışlanan bireylerin ve grupların gerçekliğine bir kapı açarak, yeni dünyanın inşa edilmesine ya da yaşanılanın dışında bir dünya için olasılıkları hayal edilmesine yardımcı olur (akt: Kim, 2016: 14). Sosyal hizmet perspektifi, bizi anlatıların insanların yaşamlarındaki özellikle de özgürleşme veya zarar verme potansiyeli olan etkilerine yönlendirir. Anlatıların sonuçları baskıcı olduklarında, mücadele etmelerini gerektirir ve bu gibi durumlarda karşıt anlatılar, insanları yaşamları için yeni ve daha yararlı hikayeler anlatmaları konusunda destekler. Ancak burada netleştirilmesi gereken önemli bir nokta vardır. Bütün meta anlatılar baskıcı sistemleri desteklemez ve bütün karşıt anlatılar özgürleştirici hedefler için çalışmaz (McKenzie-Mohr ve Lafrance, 2014, 2017).

Anlatı araştırmasında da sessizleştirilen öteki grupların bu aykırılık ve karşıtlık içeren anlatılar ön plana çıkarılarak bireyin hikayesi ele alınır. Burada nedensel ardışıklığı içeren sorular sorarak bireyin dönüm noktaları keşfedilmesi, sosyal hizmet uygulaması için de başlangıç noktalarından birini ifade eder. Toplumdaki kültürel ideolojiye uymayan deneyimler kabul görmeyeceği için hikayeleştirilmezken, sosyal değişimi sağlamak için karşıt hikâyelerin oluşturulması ve aynı zamanda yaygınlaştırılarak duyurulması da gerekmektedir. Bu bireylere ulaşarak bu sessizliğe neden olan durumlarla birlikte seslerinin yorumlayarak duyurulması noktasında çoğunlukla ötekileştirilen gruplarla çalışmalar yapan sosyal hizmet uzmanları eşsiz bir konumdadır. Anlatı araştırmasının görüşme sürecindeki zamansallık, toplumsallık ve yer vurgusu sosyal hizmet uzmanlarının müracaatçıları ile rutin görüşmelerinde de dikkate aldıkları unsurlardır. Örneğin bir sosyal inceleme raporuna bakıldığında sosyal hizmet uzmanının bu noktalara dikkat ettiği görülmektedir. Burada sosyal hizmet uzmanlarının görüşmelerinde Etherington (2011)'ın belirttiği anlatı araştırmasındaki anlatıcının sosyal ve kültürel bağlamı ele 
almasına yardımcı olan (ne, nerede, ne zaman, kiminle, neden, hangi koşullarda gibi) soruların kullanılması önemlidir. Bu sorular sosyal hizmet uzmanının, müracaatçının değerleri, inançları ve amaçları temelinde seçimleri ve eylemlerini değişen zaman içerisinde anlamasına imkan tanır. Öte yandan müracaatçının yaşadıklarının nasıl anlamlandırdığı üzerinde durulması da çalışmanın şekillendirilmesinde önemli bir bilgi sunar. Yaşamının bir parçası olan ve yaşadıklarında etkileri olan diğer bireyleri dahil etme ve dönüm noktalarını bularak hikayeyi oluşturmaya yardımcı soruları sorulmalıdır. Bu sorular özellikle de sosyal hizmet uzmanlarının, bireylerin hayatında anlatıların nasıl işlev ve sonuçları olduğunu değerlendirmesi ve ona uygun uygulamalar gerçekleştirmesi anlamında da önemlidir.

Türkiye'de Sosyal hizmet uygulamalarında anlatı anlayışının nasıl kullanıldığına dair bir çalışma olmadığı için bu konuda net bir şey söylenmesi mümkün değildir. Ancak sosyal hizmet kuram ve yaklaşımları göz önünde bulundurulduğunda, anlatı anlayışının sosyal hizmette büyük çoğunlukla kullanıldığı ifade edilebilir. Öte yandan sosyal hizmet uygulamalarında anlatı anlayışının kullanılmasının bir diğer boyutu olarak anlatı terapisi de önemli bir uygulama alanı sunmaktadır. Fırat (2019) sosyal hizmette anlatı terapisi ile ilgili çalışmasında müracaatçının sorunundaki sosyal ve kültürel süreçlere odaklanma ve meta anlatıları yapı-sökümüne uğratma yoluyla, alternatif hikayelerde yeni bir anlatının nasıl inşa edilebileceği üzerinde durmuştur.

Sosyal hizmet uzmanı, müracaatçısının gerçek duygu ve düşüncelerini ya da söylediklerinin gerçek anlamını çevresi içerisinde birey yaklaşımı ile sosyal ve kültürel bağlam, yerel bilgi, birey, grup, yapı ve sistemleri temel alarak iyice kavramaya çalışır. Bu konuda sosyal hizmet araştırmalarında da müracaatçıların hikayesine dair derinlemesine anlayış kazanılması için anlatı anlayışı içerişinde çalışmalar yapılmaya başlanması daha iyi anlamak için önemli bir yol sunmaktadır. $\mathrm{Bu}$ araştırmaların sonucunda ise özgürleştirici ve güçlendirici uygulama modelleri için bir bilgi edinilebilir. Dolayısıyla anlatı anlayışının sosyal hizmete yansımasını hem araştırma hem de uygulama bağlamında değerlendirilmesi önemlidir.

\section{SONUÇ}

Bugün sosyal bilim alanında anlatıya dönüşün 1960'lı veya 1970'li yıllardan itibaren başladığını düşünürsek bu kadar zaman içerisinde sosyal hizmet araştırmalarında anlatıya dönüş konusunda nerede olduğumuza bakmak önemlidir. Daha önce de belirtildiği üzere sosyal hizmet araştırmalarında anlatı yaklaşımı kullanılarak 
gerçekleştirilen çok az çalışma vardır. Türkiye'deki sosyal hizmet araştırmaları özelinde bakıldığında ise henüz yeni yeni çalışmalar yapılmaya başlanmıştır. Sever (2018)'in sosyal hizmet doktora tezinde kök hücre nakli olan hasta ve ailelerinin hastalık anlatıları ve Albayrak (2019)'ın ise çocuğun uyuşturucu madde bağımlılığında annelik anlatıları konularında yaptıkları anlatı araştırmaları buna örnek verilebilir. Özellikle de kadına yönelik şiddet, çocuk inmal ve istismarı gibi birçok travmatik deneyimi olan sessizleştirilmiş bireylerle çalışmaların yapıldığı sosyal hizmet araştırmalarında anlatı araştırmalarının kullanılması önemlidir. Çünkü bireylerin sessizleşmesine neden olan ve bireylerin hikayelerini şekillendiren sosyal ve kültürel bağlamı sosyal yapı içerisinde sunabilmek noktasında anlatı araştırması önemli bir yol sunmaktadır.

Sosyal hizmet lisans ve lisans üstü eğitimlerinde de anlatı anlayışına ve araştırma bilgisine ne derece yer verildiği konusu üzerinde de durulması gereklidir. Bu anlamda Türkiye'de özellikle standart olmayan sosyal hizmet eğitiminin ders içerikleri akademisyene bağlı olarak değişiklik gösterdiği için bu konuya ne kadar yer verildiğinin tespiti konusunda da bir araştırma yapılabilir.

Sosyal hizmet araştırmalarının ve eğitiminin yanında sosyal hizmet uygulamalarında anlatı anlayışının nasıl yer bulduğuna dair araştırmalar geliştirilmesi gereklidir. Riessman ve Quinney (2005) çalışmalarında belirttiği gibi anlatı teorisinin sosyal hizmet uygulamasına bilgi olarak yansımasının, anlatı yöntemlerinin sosyal hizmet araştırmalarına yansımasından daha fazla gelişmiştir. Türkiye'deki sosyal hizmet uygulamaları için de bu bilginin geçerliliğine bakmak önemlidir. Bu yüzden sosyal hizmet uygulamaları anlamında anlatı anlayışının değerlendirildiği bir sosyal hizmet araştırmasının yapılması önemli bir açığı doldurabilir.

Anlatı araştırmasını sosyal hizmetle buluşturma amacındaki bu makalede görüldüğü üzere anlatı araştırması, sosyal hizmet uzmanlarının günlük olarak yaptığı bireysel görüşmeler ve değerlendirmelerde göz önünde bulundurulması gereken bir bilgi çerçevesi sunmaktadır. Bu çerçeve, bireylerin anlatılarının ardındaki dünyada bu gerçeklikler nasıl bir araya geldiğini anlamak, bireyin anlatısını bu şekilde yapılandırmasında etkili olan faktörlerin farkına varmak ve sosyal ve kültürel bağlamları görebilmeyi sağlamaktadır. Anlatı yaklaşımı ile hareket ederken müracaatçıların deneyimlerini neden bu şekilde hikayeleştirdiğini görmek, sosyal değişim ve gelişim, bireyin özgürleşmesi ve güçlenmesi amacındaki sosyal hizmet uygulamasında odak noktalarını yakalamak anlamına gelmektedir. Bireylerin 
hikayelerinde meta ve karşıt anlatıların nerede durduğunu ve hangi amaca hizmet ettiğini görmeyi sağlayan anlatı anlayışı, sosyal hizmet uygulamasını şekillendirmede önemli bir bilgi sağlamaktadır. Özellikle de bireylerin deneyimlerini nasıl algıladıklarını sosyal ve kültürel bağlamı içeren anlatılarından görmek, bu anlatılarının bireylerin gelecekteki yaklaşımları ve eylemleri hakkında da bir bakış sunar. Bu da sosyal hizmet uygulamalarında problem alanlarını, güç alanlarını değerlendirme ve uygun bir planlama ile sosyal hizmet uygulamasının şekillendirilmesinde yardımcı olur. Bu çalışmada anlatı araştırması ile birlikte sunulan anlatı anlayışının, sosyal hizmet araştırma ve uygulamalarına daha fazla yerleşmesi gerektiğini ortaya koymaktadır.

\section{KAYNAKÇA}

Albayrak, H. (2019). Feminist sosyal çalışma perspektifiyle çocuğun uyuşturucu madde bağımlıı̆̆ında hakim annelik ideolojisine karşı annelik pratiği anlatıları. (Yayınlanmamış doktora tezi). Hacettepe Üniversitesi Sosyal Bilimler Enstitüsü Sosyal Hizmet Anabilim Dalı, Ankara.

Baldwin, C. (2013). Narrative social work: theory and application. Bristol: The Policy Press.

Bell, H. ve Hydén, M. (2017). Introducing the special issue: Social work and the narrative (half?) turn. Qualitative Social Work, Vol. 16(2), 161-165. https://doi.org/10.1177/1473325017692460

Clandinin D. J. ve Connelly F. M. (2000). Narrative inquiry: Experience and story in qualitative research. San Francisco, CA: Jossey-Bass.

Clandinin, D. J. ve Huber, J. (2010). Narrative inquiry. B. McGraw, E. Baker \& P. Perterso (Ed.), International encyclopedia of education ( $3^{r d}$ ed.). içinde (436-441. ss.) New York, NY: Elsevier. https://doi.org/10.1016/B978-0-08-044894-7.01387-7

Creswell, J. W. (2013). Nitel araştırma yöntemleri-Beş Yaklaşıma Göre Nitel Araştırma ve Araştırma Deseni. M. Bütün ve SB Demir (Çev. Ed.). Ankara: Siyasal Kitabevi.

Connelly F. M. ve Clandinin D. J. (2006). Narrative inquiry. Green J., Camili G., Elmore P. (Ed.), Handbook of complementary methods in education research içinde (477487.ss.). Mahwah, NJ: Lawrence Erlbaum.

Connelly, F.M. ve Clandinin, D.J. (1990). Stories of experience and narrative inquiry. Educational Researcher, 19(4), 2-14. https://doi.org/10.3102/0013189X019005002 
Davis, J.E. (2014). Narrative and social movements: The power of stories. Davis J.E. (Ed.) Stories of Change: Narrative and Social Movements, Kindle edition. Albany NY: SUNY Press.

Etherington, K. ve Bridges, N. (2011). Narrative case study research: On endings and six session reviews, Counselling and Psychotherapy Research, 11(1), 11-22. https://doi.org/10.1080/14733145.2011.546072

Etherington, K. (2011). Narrative approaches to case studies, [Powerpoint slides] Erişim: 09.01.2020 https://www.keele.ac.uk/media/keeleuniversity/facnatsci/schpsych/do cuments/counselling/conference/5thannual/NarrativeApproachestoCaseStudies.pdf

Fraser, H., ve MacDougall, C. (2017). Doing narrative feminist research: Intersections and challenges. Qualitative Social Work, 16(2), 240-254. https://doi.org/10.1177/1473325016658114

Fırat, E. (2019). Sosyal hizmette bir postmodern terapi olarak anlatı terapisi. Toplum ve Sosyal Hizmet, 30(1), 330-352. https://doi.org/10.33417/tsh.516870

Hall, C. J. (1997). Social Work as Narrative: Storytelling and Persuasion in Professional Texts. Oxford: Ashgate.

Hinchman, L. P. ve Hinchman, S. K. (Ed.) (1997). Memory, Identity, Community: The Idea of Narrative in the Human Sciences. Albany, NY: State University of New York Press.

Holstein, J. ve Gubrium J (2011) The constructionist analytics of interpretive practice. Denzin NK and Lincoln YS (Ed.), The SAGE Handbook of Qualitative Research (4th ed) içinde (341-357.ss.). Los Angeles: Sage.

Josselson, R. (1996). Ethics and process in the narrative study of lives. Newbury Park, CA: Sage.

Kim, J.H. (2016). Understanding Narrative Inquiry: The Crafting and Analysis of Stories as Research. Thousand Oaks, CA: Sage.

Laird, J. (1988). Women and stories: restorying women's self-constructions. M. McGoldrick, C. Anderson, \& F. Walsh (Eds.), Women infamilies: A framework for family therapy içinde (427-450.ss.). New York: Norton.

Laird, J. (Ed.) (1993). Revisioning Social Work Education: A Social Constructionist Approach. New York: Haworth.

Larsson, S. ve Sjöblom, Y. (2010). Perspectives on narrative methods in social work research. International Journal of Social Welfare, 19(3), 272-280. https://doi.org/10.1111/j.1468-2397.2009.00672.x 
McKenzie-Mohr, S. ve Lafrance, M.N. (2014). Women's discursive resistance: Attuning to counter-stories and collectivizing for change. McKenzie-Mohr $S$ ve Lafrance MN (Ed.), Women Voicing Resistance içinde (191-205. ss.). Routledge: East Sussex.

McKenzie-Mohr, S. ve Lafrance, M. N. (2017). Narrative resistance in social work research and practice: Counter-storying in the pursuit of social justice. Qualitative Social Work, 16(2), 189-205. https://doi.org/10.1177/1473325016657866

Peshkin, A. (1988). In search of subjectivity—one's own. Educational researcher, 17(7), 1721.

Polkinghorne, D.E. (1995). Narrative configuration in qualitative analysis, International Journal of Qualitative Studies in Education, 8 (1), 5-23.

Riessman, C. K. (1990). Divorce talk: Women and men make sense of personal relationships. New Brunswick, NJ: Rutgers University Press.

Reissman, C. H. (1993). Narrative Analysis. Newbury Park, CA: Sage.

Riessman, C. K. (ed.) (1994) Qualitative Studies in Social Work Research. Thousand Oaks, CA: Sage.

Riessman, C. K. (2004). Narrative Analysis. M. S. Lewis-Beck, A. Bryman ve T. Futing Liao (Ed.) Encyclopedia of Social Science Research Methods içinde (705-709. ss.). Newbury Park, CA: Sage.

Reissman, C. H. (2005). Narrative Analysis. Nancy Kelly, Christine Horrocks, Kate Milnes, Brian Roberts, David Robinson (Ed.), Narrative, memory and everyday life. İçinde (1-7.ss.). University of Huddersfield Press: Huddersfield. http://eprints.hud.ac.uk/id/eprint/4920/2/Chapter_1_Catherine_Kohler_Riessman. pdf

Reissman, C.K. ve Quinney, L. (2005). Narrative in social work a critical review, Qualitative Social Work, 4 (4), 391-412. https://doi.org/10.1177/1473325005058643

Riessman, C.K. (2002). Analysis of personal narratives. Gubrium Holstein J. (Ed.) Handbook of Interview Research içinde (695-710.ss.).. London: Sage.

Riessman C.K. (2003). Performing identities in illness narrative: Masculinity and multiple sclerosis. Qualitative $\quad$ Research $3(1)$ 5-33. https://doi.org/10.1177/146879410300300101

Riessman, C.K. (2008). Narrative Methods for the Human Sciences. CA, USA: SAGE Publications. 
Roche, S. E. ve Wood, G. G. (2005). A narrative principle for feminist social work with survivors of male violence. Affilia, 20(4), 465-475. https://doi.org/10.1177/0886109905279960

Sever, M. (2018). Kök hücre nakli olan hasta ve ailelerinin hastalık anlatıları. (Yayınlanmamış doktora tezi). Hacettepe Üniversitesi Sosyal Bilimler Enstitüsü Sosyal Hizmet Anabilim Dalı, Ankara.

Shaw, I. ve Gould, N. (Ed.) (2001). Qualitative Research in Social Work: Method and Context. Newbury Park, CA: Sage.

Soyşekerci, H. (2014). Öykü yaşamın içinde, Erişim: 12.02 .2020 https://www.artfulliving.com.tr/edebiyat/oyku-yasamin-icinde-i-1161

Uzun, E. (2015). Personal narratives of nationalism in Turkey. (Doktora tezi, The University of Edinburgh, England). Erişim: https://www.mobt3ath.com/uplode/book/book11088.pdf 